Revista de BIOLOGía Tropical

\title{
Coral communities condition in varying wave exposure: the gulf of Cazones, Cuba
}

\author{
Hansel Caballero Aragón ${ }^{1}$, Pedro M. Alcolado², Néstor Rey-Villiers² ${ }^{2}$, Susana Perera Valderrama ${ }^{3}$ \\ \& Juliett González Méndez ${ }^{3}$ \\ 1. Acuario Nacional de Cuba. 1ra y 60, Miramar, La Habana, Cuba; hanselc@acuarionacional.cu \\ 2. Instituto de Oceanología. 1ra No. 18406, Reparto Flores, Playa, La Habana, Cuba; alcolado@ama.cu, \\ nestorrvilliers@gmail.com \\ 3. Centro Nacional de Áreas Protegidas. 18 No. 4114, Miramar, Playa, La Habana, Cuba; susana@snap.cu, \\ juliett@snap.cu
}

Received 27-II-2015. C Corrected 20-IX-2015. Accepted 22-X-2015.

\begin{abstract}
Wave exposure can influence community structure and distribution of shallow coral reefs, by affecting organisms both directly and indirectly. To assess the current stony coral community condition under different degrees of wave exposure at a marine protected area of the Gulf of Cazones (SW Cuba), two expeditions were carried out in May 2010 and June 2012. Four sampling sites were sampled at reef crests (1.5 m deep), and twelve at fore-reefs, at 10, 15 and $20 \mathrm{~m}$ deep in four geographic locations. Live coral cover, species richness and composition, colony density, and maximum diameter were assessed using the AGRRA 2001 methodology. Multivariate and non-parametric statistics were applied to compare sites. The coral community structure within reef crests was not homogenous. The observed variability of indicators apparently was determined by great coral mortality events resulting from natural disturbances that occurred in the past (hurricanes, bleaching and diseases). Forereef coral communities displayed better condition and lower coral mortality than reef crests. Species richness and coral composition varied, while multivariate and statistical methods did not reveal site grouping with regard to wave exposure. The remaining biological condition indicators were similar among sites, except in the most exposed one, where coral cover and coral size were slightly lower. Wave exposure in the gulf of Cazones seemed not to have a significant influence on differences in condition and structure of the assessed coral communities. Rev. Biol. Trop. 64 (1): 78-93. Epub 2016 March 01.
\end{abstract}

Key words: coral reefs, wave exposure, coral community condition, coral cover, Cuba.

The influence of natural and anthropogenic disturbances on the condition and structure of hard coral communities is one of the fundamental problems in current environmental analyses, because the coral reefs condition has experienced a significant decline in the last decades. There are many studies describing the effect of "natural" acute disturbances like hurricanes on coral reefs (Gardner, Cote', Gill, Grant \& Watkinson, 2005; Álvarez del Castillo, Reyes-Bonilla, Álvarez-Filip, Millet-Encalada \& Escobosa-González, 2008; Fisco, 2008; Alcolado, Caballero, \& Perera, 2009a). Several papers identify human chronic disturbances such as water pollution (Kuntz, Kline, Sandin, \& Rohwer, 2005; Littler, Littler, Brooks, \& Lapointe, 2006; McClanahan, Carreiro-Silva, \& DiLorenzo, 2007; Lapointe, Langton, Bedford, \& Potts, 2010) and sedimentation (Rogers, 1990; Brown, 1997; Torres \& Morelock, 2002; Anthony, Ridd, Orpin, Larcombe, \& Lough, 2004; Fabricius, De'ath, McCook, Turak, \& Williams, 2005; Pandolfi et al., 2005; Lirman \& Fong, 2007; Hernández, Sherman, Weil, \& Yoshioka, 2009) as driver of coral reef decline.

Natural disturbances from low to moderate intensity, such as chronic wave exposure, are less studied, because their impacts are more 
difficult to measure due to the wide spatial and temporal scales through which they act upon ecosystems (Langmead \& Sheppard, 2004). Evidence suggests that wave exposure influences coral reef dynamic (Geister, 1977). Wave exposure is primarily driven by the fetch (i.e., sea surface area or distance upon wind blows to generate waves), strength and direction of the winds and may influence coral reef dynamics (Chollett \& Mumby, 2012; Chollett, Mumby, Müller-Karger, \& Hu, 2012). This factor acting with great magnitude can influence the community structure and distribution of corals directly through mechanical stress, by dislodging or breaking them (Denny, 1994), and indirectly through sediment flux (Wolanski, Fabricius, Spagnol, \& Brinkman, 2005). Reef sites with relatively high sedimentation rates (induced by waves) have fewer coral species, lower live coral cover and growth rates, greater abundance of branching forms, reduced coral recruitment, decreased calcification, decreased net productivity of corals, and slower rates of reef accretion (Rogers, 1990).

As example of coral reefs with influence of disturbances from variable intensity, we chose the coral communities of the gulf of Cazones (SW Cuba). This area is located within the National Park of Zapata Swamp (Marine Protected Area of Managed Resources declared Biosphere Reserve and Ramsar Site), away from human settlements (towns, tourist facilities, fishing centers) and urban pollution sources. According their geographical position, two types of mechanical disturbances can affect the coral reefs: the chronic exposure to waves, and acute episodic physical disturbance from tropical cyclones. This was verifiable through to remote sensors charts of Chollett et al. (2012).

The goal of this study was to evaluate the structure and condition of coral communities located in sites with variable wave exposition. We asked some questions: Can wave exposure influence biological indicators like live coral cover, density and colony size, and coral composition across a light depth gradient?

\section{MATERIALS AND METHODS}

Study area description: The study area is located at the North side within the gulf of Cazones, next to the Peninsula of Zapata, in the South coast of the central part of Cuba (Fig. 1). This gulf is a deep and narrow ocean tongue that enters northward near to the mainland coast ending as a large circular feature better known as "Ensenada de Cazones". The gulf is surrounded by keys and extensive mangrove forests of the mainland swampy coast that attenuates extreme episodes of terrestrial runoff on coral reefs, particularly during the rainy season. According to Pavlidis, Ionin, Ignatov, LLuis-Riera \& Avelio (1973), surface currents in the gulf of Cazones moves toward the West driven by the predominant wind pattern from
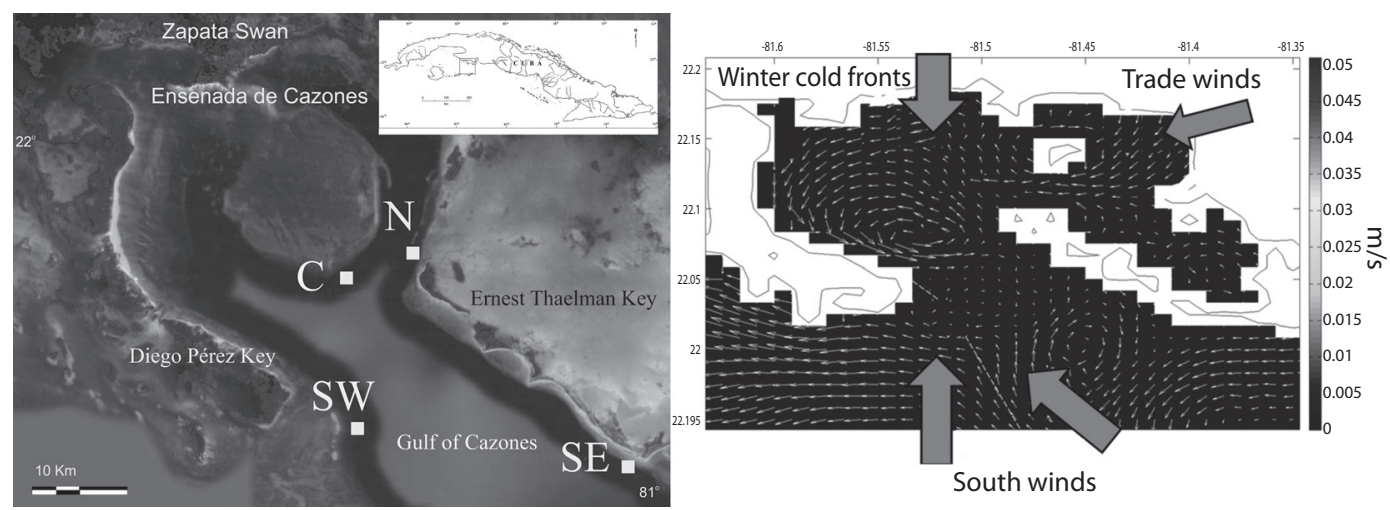

Fig. 1. Map of study area. Left: Geographic location of the gulf of Cazones; right: General trend of winds and surface circulation. Modified scheme from Arriaza et al. (2012). See codes of coral reefs in Table 1. 
Northeast-East to West. Inside the West part of the gulf, slow cyclonic circulation pattern is present (Fig. 1). This would drag and circulate the nutrients coming from the swampy coast (Alcolado et al., 2013, according to the circulation model of Arriaza et al., 2012).

Coral reefs in the gulf of Cazones can be classified as fringing reefs (with or without reef crest zones). From the outer borders of the reef crests a flat rocky/sandy zone extends down to $10 \mathrm{~m}$ deep. Spur and groove reef systems extend deeper providing more architectural complexity and at 15 to $17 \mathrm{~m}$ an abrupt deep fore-reef slope $\left(80^{\circ}\right)$ is present.

Coral reefs in the area have experienced different degrees of wind exposure. Dominant winds include the Trade Winds (from the East and Northeast), Northern winter winds, and sporadic strong "South winds" events (Ballester, 1997). The fetch that influence wave from the North and trade winds on the area is reduced by the land masses. Wave generation by Southwestern winds is reduced given the extension of the very shallow platform of the gulf of Batabanó (Alcolado et al., 2013). Thus, the Southern and Southeastern winds produce waves impact the most these coral reefs. These Southern winds are meteorological events associated to low-pressure centers that move on the Gulf of Mexico (generally between September and May), and they precede the winter cold fronts, sometimes reaching wind speeds of 100 $\mathrm{km} / \mathrm{h}$ (Ballester, 1997). The gulf of Cazones is also located in a zone sometimes affected by hurricanes and tropical storms (five hurricanes between 1980 and 2010 according to www.noaa.gov).

Survey sites and data analyses: Two expeditions were carried out: in May of 2010 (to evaluate fore-reefs) and June of 2012 to evaluate crest reefs). Four coral reef areas or location sites were chosen with different degrees of wave exposure (Fig. 1) (Table 1). Wave exposure values were obtained from remote sensors charts of Chollett et al. (2012) where the exposure of a location is a function of the shape of the basin, speed and direction of winds. Chollett et al. (2012) measured fetch using the global, self-consistent, hierarchical,

TABLE 1

Geographical location of coral reefs sites, depth and type of habitats

\begin{tabular}{lcccclcc}
$\begin{array}{c}\text { Coral reef } \\
\text { (location) }\end{array}$ & $\begin{array}{c}\text { Codes of } \\
\text { sites }\end{array}$ & LN & LW & Depth (m) & Ecological Zone & $\begin{array}{c}\text { WE } \\
(\text { Ln J / m })^{3)}\end{array}$ & DAH \\
North (N) & N1 & 22.1018 & 81.4901 & 10 & Spur and groove & 4.5124 & 7.0 \\
& N2 & 22.1018 & 81.4901 & 15 & Spur and groove & 4.5124 & 7.0 \\
& N3 & 22.1018 & 81.4901 & 20 & Fore-reef slope & 4.5124 & 7.0 \\
Central (C) & C1 & 22.1043 & 81.5159 & 1.5 & Reef crest & 5.4131 & 7.0 \\
& C2 & 22.1043 & 81.5159 & 10 & Spur and groove & 5.4131 & 7.0 \\
& C3 & 22.1043 & 81.5159 & 15 & Spur and groove & 5.4131 & 7.0 \\
& C4 & 22.1043 & 81.5159 & 20 & Fore-reef slope & 5.4131 & 7.0 \\
Southwest (SW) & SW1 & 22.0379 & 81.5173 & 1.5 & Reef crest & 5.8528 & 7.0 \\
& SW2 & 22.0237 & 81.5173 & 1.5 & Reef crest & 6.0200 & 7.0 \\
& SW3 & 22.0266 & 81.5150 & 10 & Spur and groove & 5.8528 & 7.0 \\
& SW4 & 22.0266 & 81.5150 & 15 & Spur and groove & 5.8528 & 7.0 \\
& SW5 & 22.0266 & 81.5150 & 20 & Fore-reef slope & 5.8528 & 7.0 \\
Southeast (SE) & SE1 & 22.0125 & 81.3417 & 1.5 & Reef crest & 6.1615 & 10.0 \\
& SE2 & 22.0208 & 81.3875 & 10 & Spur and groove & 5.9768 & 8.0 \\
& SE3 & 22.0208 & 81.3875 & 15 & Spur and groove & 5.9768 & 8.0 \\
& SE4 & 22.0208 & 81.3875 & 20 & Fore-reef slope & 5.9768 & 8.0 \\
\hline
\end{tabular}

Values of wave exposition (WE) and danger average of hurricanes (DAH) for the period 1980 at 2008 were calculated according to charts of remote sensors of Chollet et al. (2012). 
high-resolution shoreline database (GSHHS version 1.5, Wessel \& Smith, 1996), speed and direction of winds were acquired from the QuikSCAT (NASA) satellite scatterometer from 1999 to 2008. The danger average of hurricanes for the period 1980 at 2008 was calculated as the product of the frequency of hurricanes by the intensity average (Saffir-Simpson) according to Chollett et al. (2012) (Table 1).

Four sites were located in reef crest habitat at about $1.5 \mathrm{~m}$ deep (except for the $\mathrm{N}$ location that lacked zone). The SW location presented two reef crest sites SW1 and SW2 due to the great longitude of the crest. For all four locations, we surveyed coral communities at three depths (10, 15 and $20 \mathrm{~m}$ deep, Table 1). Between 14 and 22 replicates benthic $10 \mathrm{~m}$ long transects were haphazardly placed at each reef site (Appendix II). Sampling methods applied to indicators were those from AGRRA (2001). Live coral cover was calculated considering the percentages of live tissue intersected by the transect line. Coral colonies larger than $10 \mathrm{~cm}$ in diameter that intercepted the transect line, were counted and identified to specie. Maximum diameter of each intercepted colony (observed from above and including the dead parts) was measured. Standing coral colonies with $100 \%$ of mortality were not included in the analysis of coral density and size.

To estimate the variation of biological indicators (live coral cover, density, and maximum diameter) among sites (crest and forereefs separately), an analysis of permutational variance (PERMANOVA, Anderson, Gorley, $\&$ Clarke, 2008) was performed, using sites as fixed factor for reef crests (one-way factorial design), and locations and depth as fixed factors for fore-reefs (two-way factorial design). The Bray- Curtis similarity index with 999 permutations and 0.05 of significance was applied. A square root transformation was applied to each data matrix.

Differences in coral community structure among sites within reef habitats were analyzed according to coral relative abundance. Species accumulative curves were made, and a nonmetric multidimensional ordination analysis
(nMDS) was used based on the Bray-Curtis similarity index and the group-average linking method. Only the $95 \%$ of species (in decreasing order) was used in the analysis and was transformed to the square root. The similitude matrix obtained was analyzed by PERMANOVA (999 permutations and 0.05 significance) to determinate statistical variation, using sites as fixed factor for reef crests (one-way factorial design), and locations and depth as fixed factors for fore-reefs (two-way factorial design).

All tests were performed using the PRIMER 6 software and the PERMANOVA version of this program (Anderson et al., 2008). To build graphics the Microsoft Excel 2010 and the Statistica 6.0 programs (StatSoft Inc., 2002) were used.

\section{RESULTS}

Live coral cover was significantly different among reef crest sites $(\mathrm{p}=0.001)$. The highest live coral cover $(62.8 \pm 3.9 \%$, mean \pm se) was found at $\mathrm{C} 1$, while the lowest at SE1 $(14.2 \pm 1.8 \%)$ (Fig. 2A). Coral density ( $\mathrm{p}=$ $0.047)$ had the highest value also in C1 (8.0 \pm 0.5 colonies $/ 10 \mathrm{~m}$ ) and the lowest at SE1 (5.9 \pm 0.7 colonies / $10 \mathrm{~m}$ ) (Fig. 2B). Mean coral colony maximum diameter in $\mathrm{C} 1(121 \pm 6.1$ $\mathrm{cm})$ was significantly higher $(\mathrm{p}=0.001)$ than in the remaining reef crest sites (Fig. 2C). See the PERMANOVA complete results in Appendix I, Appendix II, Appendix III and Appendix IV of supporting information.

A total of 14 species of scleractinian corals and one hydrocoral were observed at the reef crest sites. SE1 and $\mathrm{C} 1$ sites had the highest number of species (11 species), followed by SW1 and SW2 (Fig. 3A). Among coral species within each site, $\mathrm{C} 1$ presented the highest relative abundance (82\%) of Acropora palmata (Lamarck, 1816) while Millepora complanata (Lamarck, 1816) predominated in SW2 and SW1 (61 \% and $53 \%$, respectively). Porites astreoides (Lamarck, 1816) and M. complanata predominated in SE1 (36\% and $22 \%$, respectively). At SE1 we observed that all colonies of A. palmata were fully dead standing colonies. 
See table of relative abundance of coral per site in Appendix II of supporting information.

The nMDS and PERMANOVA analyses (based on coral relative abundance) showed significant differences among crests with regard to community composition ( $\mathrm{p}=0.001)$. Only SW1 and SW2 were similar (Fig. 4). See the PERMANOVA complete results in Appendix I and Appendix IV of supporting information.

Coral indicators in fore-reef sites showed no significant interaction between location and depth through the PERMANOVA analysis $(p=0.715)$. Total live coral cover average of fore- reef sites was $23 \pm 0.5 \%$. SE1 had the lowest coral cover $(20.4 \pm 1.8)$ at $10 \mathrm{~m}$ deep (Fig. 2D), while there were not significant differences among sites at $15 \mathrm{~m}$ and $20 \mathrm{~m}$ in depth. Coral colony density was higher in $\mathrm{C} 2$ $(9.8 \pm 0.7$ colonies $/ 10 \mathrm{~m})$ than in the remaining sites at $10 \mathrm{~m}, 15 \mathrm{~m}$ and $20 \mathrm{~m}$ deep (Fig. $2 \mathrm{E})$. The biggest corals were found always in sites of $\mathrm{C}$, while the lowest ones in the sites of
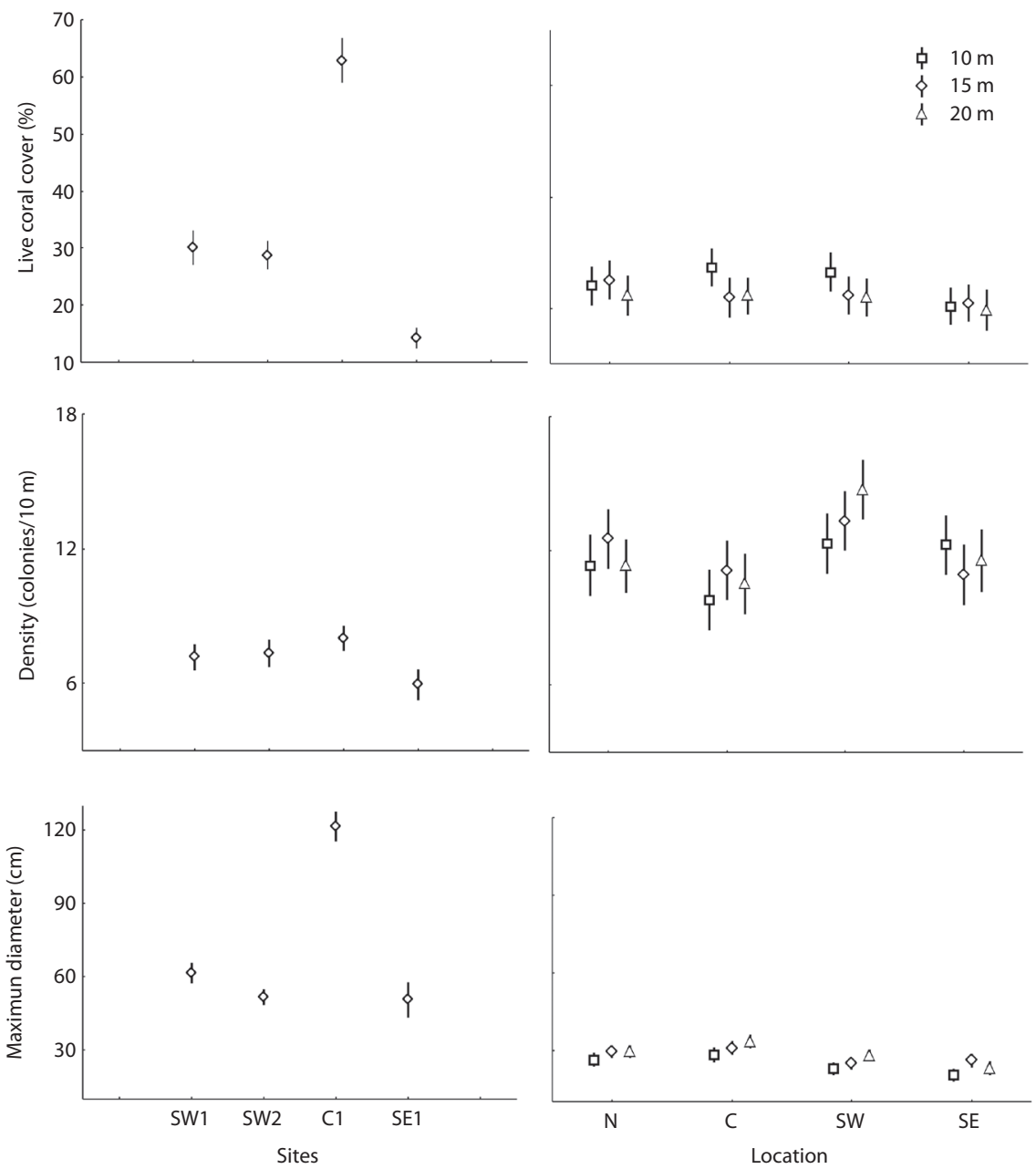

Fig. 2. Coral biological indicators (mean \pm standard error). A: Live coral cover in reef crest sites; B: Density in reef crest sites; C: Maximum diameter in reef crest sites; D: Live coral cover in fore-reef sites; B: Density in fore-reef sites; C: Maximum diameter in fore-reef sites. See codes of sites in Table 1. 
A

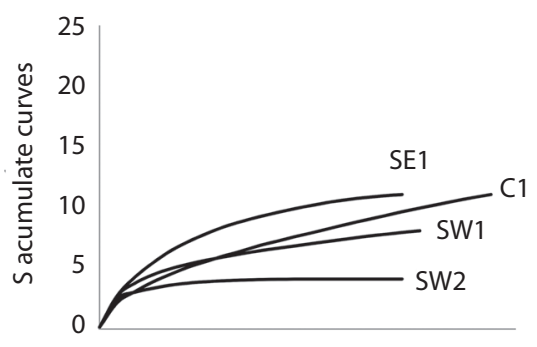

C

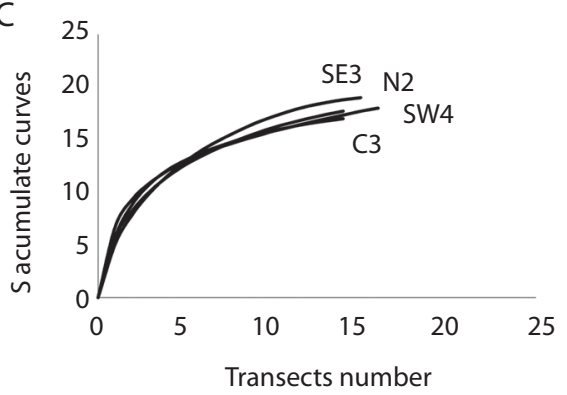

B

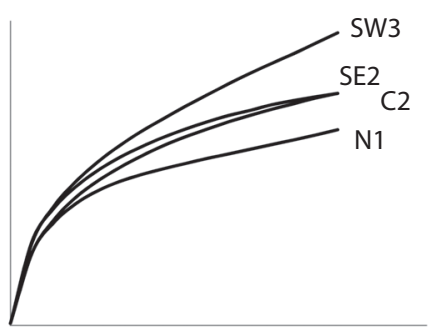

D

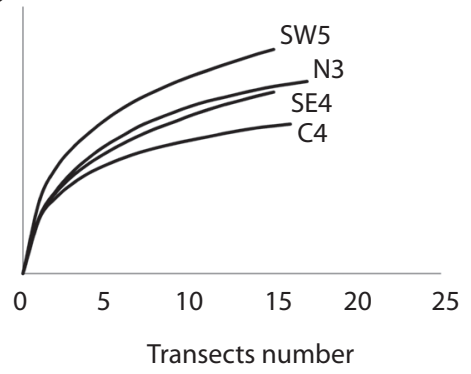

Fig. 3. Result of accumulative curves of number of species (S)/number of transects; A: Crest sites; B: $10 \mathrm{~m}$ deep sites; C: $15 \mathrm{~m}$ deep sites and D: $20 \mathrm{~m}$ deep sites.

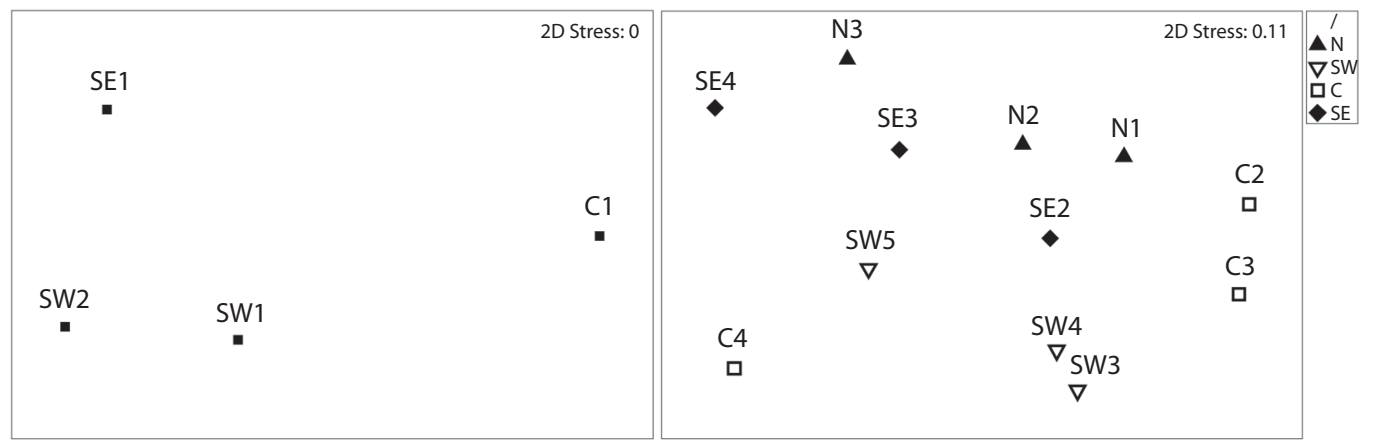

Fig. 4. Results of nMDS analysis. Left: Crest sites; Right: Fore-reefs sites. See codes of sites in Table 1.

SW (Fig. 2F). See the PERMANOVA complete results in Appendix III and Appendix V of supporting information.

At fore-reef sites, coral species richness ranged from $13(\mathrm{C} 4)$ to 23 (SW3). In general, the highest diversity of coral species was found in the fore-reef sites of the SW area. At $10 \mathrm{~m}$ deep, the lowest slope of the cumulative species curve was observed in $\mathrm{N} 1$; at $15 \mathrm{~m}$ deep all species accumulative curves showed similar tendency, and at $20 \mathrm{~m}$ deep, the lowest values belonged to C4 (Fig. 3 B, Fig. 3C and Fig. 3D).

The relatively dominant species among corals at the fore-reef $10-15 \mathrm{~m}$ deep sites was Siderastrea siderea Ellis \& Solander, 1786, especially within the N and SE locations. The specie Orbicella faveolata Ellis \& Solander, 1786 was relatively abundant at the deeper sites, and at C and SW fore-reef sites. Other fairly abundant species were Agaricia 
agaricites (Linnaeus, 1758) (SW3 and SW5) and $P$. astreoides (C3 and SE2). O. annularis Ellis \& Solander, 1786, also showed relatively high percentages at SW2 and SW3. See table of relative abundance of coral per site in Appendix II of supporting information.

The nMDS ordination analysis for the fore-reef zones displayed a dispersed pattern (Fig. 4). The PERMANOVA analysis showed a significant interaction between location and depth for fore-reef sites $(\mathrm{p}=0.001)$. The sites at 10 and $20 \mathrm{~m}$ deep display significant differences while N2 and SE3 sites at $15 \mathrm{~m}$ were similar. See the PERMANOVA complete results in Appendix III and Appendix V of supporting information.

\section{DISCUSSION}

At the reefs crests of the gulf of Cazones, the highest values for live coral cover, and colony size were found in the less exposed site $(\mathrm{C} 1)$. This site had a relatively high dominance of healthy colonies of $A$. palmata, which used to be the main reef-builder coral species of shallow reefs in the Caribbean (Aronson \& Precht, 2001; Pandolfi \& Jackson, 2001; Acropora Biological Review Team, 2005). However, wave exposure does not seem to be the only direct cause of the main differences found among crests. According to Alcolado et al. (2010), in the past decades SW1, SW2 and SE1 had live coral cover and community composition similar to those of $\mathrm{C} 1$ today. In 2001, SW1 had live coral cover of $48.5 \%$ in average (Alcolado et al., 2010), with a great number of live colonies of $A$. palmata, many of which were still standing but dead in the present study. It is likely that these reef crests were healthier in the 1980s resembling the typical structure of crest zone of Caribbean shallow reefs described by Geister (1977).

It is possible that the differences in the biological indicators between $\mathrm{C} 1$ and the rest of reef crests were apparently a consequence of high coral mortality events that occurred in SW and SE by the end of last century. This suggests that $\mathrm{C} 1$ has been more resilient against natural disturbances causing high mortality to $A$. palmata. This species has experienced a significant regional decline as a result of storms, bleaching events, predation and epizootic diseases (Aronson \& Precht, 2001; Patterson et al., 2002; Precht, Bruckner, Aronson, \& Bruckner, 2002; Rogers \& Miller, 2006; Cramer, Jackson, Angioletti, Leonard-Pingel, \& Guilderson, 2012; Jackson, Donovan, Cramer, \& Lam, 2014).

The mean live coral cover in $\mathrm{C} 1(\sim 60 \%)$ was higher than those reported for other reef crests through the Cuban archipelago, where the "healthiest" reef crests do not exceed 40 $\%$, and a large number of them are less $10 \%$, revealing a critical state (González-Ferrer et al., 2007, Caballero, Alcolado, \& Semidey, 2009; Alcolado et al., 2009b, 2010). Apparently this location has experienced stable conditions for Acropora populations. Past studies showed similar cover in 2001, and was approximately $70 \%$, in the 1980s (Alcolado et al., 2010). Several possible explanations for healthy Acropora populations at this site are: (1) a proliferation by asexual reproduction of a few clones genetically resilient to the pathogens affecting the Caribbean; (2) faster recovery by re-growth of surviving colonies; (3) that the pressures affecting the rest of the sub region have not targeted these sites (or colonies) to the same extent (Alcolado et al., 2010); or (4) a greater and faster stabilization opportunity of $A$. palmata branch fragments after storms and hurricanes (Alcolado et al., 2013). The sheltered condition of the $\mathrm{C} 1$ should have strongly stimulated coral recovery after extreme events. It should have also significantly favored a higher coral recruitment and survival of young colonies. Another of the most plausible explanation (5) of why this site has more Acropora cover is high degree of self-recruitment due to that oceans currents keep coral larvae in that spot. The cyclonic surface water circulation around $\mathrm{C} 1$ area could prevent coral gametes and larvae from escaping the area, increasing self-recruitment and concentrate productivity contributing to a higher coral growth and survivorship (Alcolado et al., 2013). 
Additionally (6), a higher water fertility and biological richness could provide better condition at $\mathrm{C} 1$. Fernández de la Llera, Hidalgo-González, López-García, García-Ramil and Penié-Rodríguez (1990) described a decreasing gradient of concentration of nutrients $(\mathrm{N}$ and P) from Zapata swamp to the South of the gulf of Cazones. The proximity of $\mathrm{C} 1$ to Zapata swamp and very shallow sheltered lagoons behind of Thaelmann key (both rich in mangrove forests), should have been favorable, considering the provision of non-excessive nutrients that enable greater concentrations of different components of plankton as shown by other researches in the study area (bacterioplankton: Lugioyo, 2003; Lugioyo, Miravet, Pérez, Álvarez, \& Espinosa, 2007; phytoplankton: Pérez, Gil, \& Loza, 1990; Loza, 2010; microzooplankton: Orozco-Llerena, 1997; fish larvae: Gutiérrez, Montolio, \& Frías, 1990; and stage 1 lobster larvae: Alfonso, Frias, Campos, $\&$ Baisre, 1991). The plankton should be favoring corals through heterotrophy, making them more resistant (Fabricius, De'ath, McCook, Turak, \& Williams, 2005; Schuttenberg \& Marshall, 2008) and will be to recover faster.

The worst coral reef crest condition was observed at SE1, but as this site has not been studied before it is not possible to know mortality causes and time of occurrence. It is possible that due to the exposed location of SE1 in the Southern end of the gulf, the destructive effects of hurricanes at the beginning of the century were more intense at this site with no recovery overtime. Storms can be powerful drivers of changes for coral reefs (Álvarez-Filip, Dulvy, Gill, Côté, \& Watkinson, 2009), and the effect of hurricanes today may be stronger than in the past (Mumby \& Steneck, 2008).

In fore-reefs sites, coral cover, and coral size were slightly lower at SE at $10 \mathrm{~m}$ deep. This is the most exposed site studied and wave exposure is expected to be stronger, the sediment suspension to be higher, the slope of the bottom is lower favoring sediment accumulation (Sheppard, 1982). Coral cover was over $20 \%$ at the $10 \mathrm{~m}$ deep sites in the locations more exposed to wave (SE and SW). However, lower coral cover has been observed in other Cuban reefs at the same depth under different wave exposure regimes. For example, coral cover at Bajos de Sancho Pardo (NW Cuba) is $<13 \%$. These reefs are exposed to strong north winds due to cold fronts that create wave exposure average of $7.2 \mathrm{jm} / 3$ (according to Chollet et al., 2012 charts) and have been often affected by tropical storms (Caballero \& Alcolado, 2011). Similar conditions are also seen in coral reefs of Santa Lucía (NE Cuba) exposed to fairly constant trade winds with wave exposure average of $7.6 \mathrm{jm} / 3$. At both reefs, average coral cover was below $13 \%$ (Busutil, Caballero, Hidalgo, Alcolado-Prieto, Alcolado, \& Martínez-Daranas, 2011; Caballero \& Alcolado, 2011). Similarly, coral reefs of Cabo San Antonio, that are exposed to both strong Southern wind events (wave average of $6.7 \mathrm{jm} / 3$ ) and frequent hurricanes, show a mean coral cover $<10 \%$ at $10 \mathrm{~m}$ deep, and their coral communities are comprised of small colonies, mainly of $S$. siderea (Perera, Alcolado, Caballero, de la Guardia, \& Cobián, 2013).

In general, the fore-reef sites of the gulf of Cazones displayed bigger live coral cover that others Cuban coral reefs. In our study, mean coral cover for fore-reef sites was 23 $\%$. In contrast, coral cover varied between 8 and $18 \%$ at fore-reef sites from Cayo Coco (NE Cuba) (Clero-Alonso et al., 2006). The weighed national average of live coral cover estimated by Alcolado et al. (2009b) for years 2003-2009 was $13.4 \%$. Finally, between 2007 and 2010, 74 fore reef sites from Western Cuba presented a mean coral cover of $15.6 \%$ (Caballero, Alcolado, \& Semidey, 2009; Caballero \& Alcolado, 2011; Perera et al., 2013).

Species richness and coral community composition were not related to wave exposure in fore-reef sites. Coral composition was very variable among locations and depths with no clear grouping in the ordination analysis. Species recognized as resistant to high water turbulence and to sedimentation $(S$. siderea, $P$. astreoides, $M$. cavernosa and S. intersepta, according to Herrera \& Martínez-Estallela, 1987; Meesters, Bos, \& Gast, 1992; Torres \& 
Morelock, 2002) showed a variable and random relative abundance among sites, being equally abundant in both sheltered and exposed sites.

We concluded that different wave exposure in the gulf of Cazones seems not to have significant influence on the structure and the condition of coral communities. The reef crests were not homogenous. Differences observed are related with the corals health that is associated with previous mortality events. One of the crests has been more resilient that the others. Species richness, coral composition and the other biological indicators did not appear to be fully related to wave exposure in forereef, except at $10 \mathrm{~m}$ of $\mathrm{SE}$, which is the most exposed site where coral cover and coral size were slightly lower.

\section{ACKNOWLEDGMENTS}

We are grateful for the field assistance provided by Danay Macías, Zaimiury Hernández and Víctor Isla. We appreciate the time and efforts of Loraine Ledón and Julio Baisre for assisting in the English translation of the manuscript. We are very grateful for the assistance provided by Ileana Chollett of to offer the charts of remote sensors of wave unselfishly.

\section{RESUMEN}

Condición de comunidades coralinas con diferente exposición al oleaje: El Golfo de Cazones, Cuba. El oleaje es una perturbación natural que puede inferir en la estructura y condición de los arrecifes de coral someros, afectando los organismos directa e indirectamente. Para evaluar la condición de comunidades de corales con diferente exposición al oleaje, se realizaron dos expediciones al Área Marina Protegida del Golfo de Cazones durante mayo 2010 y junio 2012. Se escogieron cuatro arrecifes (localidades) ubicados en posiciones diferentes del golfo. Se ubicaron cuatro sitios en la zona de cresta $(1.5 \mathrm{~m}$ de profundidad) y 12 en la zona de arrecife frontal (en cuatro localidades a 10, 15 y $20 \mathrm{~m}$ de profundidad) donde se replicaron transectos lineales (10 $\mathrm{m}$ de largo) de muestreo. Se evaluó la cobertura de coral vivo, riqueza y composición por especies, densidad y diámetro máximo de las colonias mediante la metodología AGRRA 2001. Para la comparación entre sitios se aplicaron métodos evaluativos multivariados y análisis estadísticos no paramétricos. La estructura y condición de la comunidad de corales en las crestas fue distinta pero la variabilidad observada parece responder a grandes eventos de mortalidad producto de huracanes, blanqueamientos y enfermedades del pasado. La condición de los arrecifes frontales fue más favorable observándose menor mortalidad coralina. La riqueza y composición por especies fue variable y los métodos estadísticos y multivariados no definieron grupos de sitios con similitud respecto a la exposición al oleaje. Los demás indicadores biológicos de condición fueron parecidos entre sitios, excepto en el más expuesto al oleaje, donde la cobertura y la talla de los corales fueron ligeramente inferiores. En general, la diferente influencia del oleaje dentro del golfo de Cazones, parece no afectar significativamente la estructura y condición de las comunidades coralinas.

Palabras claves: arrecifes de coral, exposición al oleaje, comunidades coralinas, cobertura de coral, Cuba.

\section{REFERENCES}

Acropora Biological Review Team. (2005). Atlantic Acropora Status Review Document (Report to National Marine Fisheries Service). Unite States: Southeast Regional Office.

Alcolado, P. M., Hernández-Muñoz, D., Caballero, H., Busutil, L., Perera, S., \& Hidalgo, G. (2009a). Efectos de un inusual período de alta frecuencia de huracanes sobre el bentos de arrecifes coralinos. REVMAR, 1, 74-94.

Alcolado, P. M., Caballero, H., \& Perera, S. (2009b). Tendencia del cambio en el cubrimiento vivo por corales pétreos en los arrecifes coralinos de Cuba. Serie Oceanológica, 5, 1-23.

Alcolado, P. M., Morgan, I. E., Kramer, P. A., Ginsburg, R. N., Blanchon, P., de la Guardia, E., ... Hernández, M. (2010). Condition of remote reefs off southwest Cuba. Ciencias Marinas, 36, 179-197.

Alcolado, P. M., Caballero, H., Lara, A., Arriaza, L., Rey-Villiers, N., Lugioyo, G. M., ... Castellanos, S. (2013). La resiliencia en crestas arrecifales del este del Golfo de Batabanó, Cuba, y sus factores determinantes probables (Informe de Investigación). Cuba: Instituto de Oceanología.

Alfonso, I., Frias, M. P., Campos, A., \& Baisre, J. A. (1991). Distribución y abundancia de larvas de la langosta Panulirus argus en aguas alrededor de Cuba. Revista de Investigaciones Marinas, 12, 5-19.

Álvarez del Castillo, P. A., Reyes-Bonilla, H., ÁlvarezFilip, L., Millet-Encalada, M., \& Escobosa-González, L. E. (2008). Cozumel Island, México: A disturbance history. Proceedings of the 11th International Coral Reef Symposium, 18, 7-11.

Álvarez-Filip, L., Dulvy, N. K., Gill, J. A., Côté, I. M., \& Watkinson, A. R. (2009). Flattening of Caribbean coral reefs: Region-wide declines in architectural 
complexity. Proceeding of Real Society of Biology, $276,1-7$.

Anderson, M. J., Gorley, R. N., \& Clarke, K. R. (2008). PERMANOVA + for PRIMER: Guide to Software and Statistical Methods. Plymounth, UK: PRIMER-E.

Anthony, K. R. N., Ridd, P. V., Orpin, A., Larcombe, P., \& Lough, J. M. (2004). Temporal variation in light availability in coastal benthic habitats: effects of clouds, turbidity and tides. Limnology and Oceanography, 49, 2201-2211.

Aronson, R. B., \& Precht, W. F. (2001). White-band disease and the changing face of Caribbean coral reefs. Hydrobiologia, 460, 25-38.

Arriaza, L., Hernández, M., Lorenzo, S., Olivera, J., Rodas, L., Montesino, D., ... Navarro-Padrón, J. (2012). Modelación numérica de corrientes marinas alrededor del occidente de Cuba. Serie Oceanológica, 10, 11-22.

Ballester, M. (1997). Los sures en la mitad occidental de Cuba: cronología actualizada, potencial de daños y tendencias. SOMETCUBA, 3, 25-36.

Brown, B. E. (1997). Disturbance to coral reefs in recent times. In C. Birkeland (Ed.), Life and Death of Coral Reefs (pp. 354-379). New York: Chapman Hill.

Busutil, L., Caballero, H., Hidalgo, G., Alcolado-Prieto, P., Alcolado, P. M., \& Martínez-Daranas, B. (2011). Condición del bentos de los arrecifes coralinos de Santa Lucía (nordeste de Cuba) antes y después del paso del huracán Ike. Serie Oceanológica, 8, 30-42.

Caballero, H., Alcolado, P. M., \& Semidey, A. (2009). Condición de los arrecifes de coral frente a costas con asentamientos humanos y aportes terrígenos: El caso del litoral habanero, Cuba. REVMAR, 1, 49-72.

Caballero, H., \& Alcolado, P. M. (2011). Condición de arrecifes de coral sometidos a presiones naturales recientes: Bajos de Sancho Pardo, Cuba. REVMAR 3, 51-65.

Chollett, I., \& Mumby, P. J. (2012). Predicting the distribution of Montastraea reefs using wave exposure. Coral Reefs, 31, 493-503.

Chollett, I., Mumby, P. J., Müller-Karger, F. E., \& Hu, C. (2012). Physical environments of the Caribbean Sea. Limnology and Oceanography, 57, 1233-1244.

Clero-Alonso, L., Pina, Hernández, F. L., Martín, F., Zúñiga, D., ... Caldwell. S. (2006). Biota acuática del norte de la provincia Ciego de Ávila. In Ecosistemas costeros: biodiversidad y gestión de recursos naturales (Compilación por el XV Aniversario del Centro de Investigaciones de Ecosistemas Costeros) (pp.182-184). Cuba: CIEC.
Cramer, K. L., Jackson, J. B. C., Angioletti, C.V., LeonardPingel, J., \& Guilderson, T. P. (2012). Anthropogenic mortality on coral reefs in Caribbean Panama predates coral disease and bleaching. Ecology Letters, 15, 561-567.

Denny, M. (1994). Extreme drag forces and the survival of wind and water-swept organisms. Journal Experimental Biological, 194, 97-115.

Fabricius, K., De'ath, G., McCook, L., Turak, E., \& Williams, D. M. (2005). Changes in algal, coral and fish assemblages along water quality gradients on the inshore Great Barrier Reef. Marine Pollution Bulletin, 51, 384-398.

Fernández de la Llera, M., Hidalgo-González, R. M., López-García, D., García-Ramil, I., \& Penié-Rodríguez, I. (1990). Caracterización hidroquímica de la Fosa de Jagua y de la Zona Económica Exclusiva al sur de Cuba (Informe Final). Cuba: Instituto de Oceanología, Academia de Ciencias.

Fisco, D. (2008). Post hurricane dynamics and status of coral reefs St. Croix, US Virgin Islands. Proceedings of the 11th International Coral Reef Symposium, 23, 1098-1102.

Gardner, T. A., Cote', I. M., Gill, J. A., Grant, A., \& Watkinson, A. R. (2005). Hurricanes and caribbean coral reefs: impacts, recovery patterns, and role in longterm decline. Ecology, 86, 174-184.

Geister, J. (1977). The influence of wave exposure on the ecological zonation of Caribbean coral reefs. In D. L. Taylor (Ed.), Proc. 3rd Int. Coral Reef Symp (pp. 23-29). Florida, USA: Rosenstiel School of Marine and Atmospheric Science.

González-Ferrer, S., Cantelar, K., Pina, F., Jiménez, A., Espinosa, J., Hernández, M., \& Hernández, J. L. (2007). Estado de los ecosistemas marinos y costeros, y algunas características ambientales y tendencias. In P. M. Alcolado \& M. Arellano-Acosta, (Eds.), Ecosistema Sabana-Camagüey. Estado actual, avances y desafios en la protección y uso sostenible de la biodiversidad (pp. 38-45). Cuba: Proyecto PNUD/GEF Sabana- Camagüey, CUB/98/G32, CUB/99/G81.

Gutiérrez, E., Montolio, M., \& Frías, M. P. (1990). Composición de la comunidad ictioplanctónica de las aguas territoriales al sur de Cuba. La Habana, Cuba: Memorias del II Congreso de Ciencias del Mar.

Hernández, R., Sherman, C., Weil, E., \& Yoshioka, P. (2009). Spatial and temporal patterns in reef sediment accumulation and composition, southwestern insular shelf of Puerto Rico. Caribbean Journal Science, 45, 138-150. 
Herrera, A., \& Martínez-Estallela, N. (1987). Efecto de la contaminación sobre las comunidades de corales escleractíneos al oeste de la Bahía de La Habana. Simposio de Ciencias del Mar, VII Jornada Cientifica del Instituto de Oceanología XX Aniversario, 2 , 253-257.

Jackson, J. B. C., Donovan, M. K., Cramer, K. L., \& Lam, V. V. (2014). Status and Trends of Caribbean Coral Reefs: 1970-2012. Gland, Switzerland: Global Coral Reef Monitoring Network, IUCN.

Kuntz, N. M., Kline, D. I., Sandin, S. A., \& Rohwer, F. (2005). Pathologies and mortality rates caused by organic carbon and nutrient stressors in three Caribbean coral species. Marine Ecology Progress Series, 294, 173-180.

Langmead, O., \& Sheppard, C. (2004). Coral reef community dynamics and disturbance: a simulation model. Ecology Modern, 175, 271-290.

Lapointe, B. E., Langton, R., Bedford, B. J., Potts, A. C., Day, O., \& Hud, C. (2010). Land-based nutrient enrichment of the Buccoo Reef Complex and fringing coral reefs of Tobago, West Indies. Marine Pollution Bulletin, 60, 334-343.

Lirman, D., \& Fong, P. (2007). Is proximity to land-based sources of coral stressors an appropriate measure of risk to coral reefs? An example from the Florida Reef Tract. Marine Pollution Bulletin, 54, 779-791.

Littler, M. M., Littler, D. S., Brooks, B. L., \& Lapointe, B. E. (2006). Nutrient manipulation methods for coral reef studies: A critical review and experimental field data. Journal Experimental Marine Biological and Ecology, 336, 242-253.

Loza, S. (2010). Estructura y funcionamiento del fitoplancton menor de $133 \mu \mathrm{m}$ en las aguas oceánicas de Cuba (Tesis de Doctorado). Universidad de la Habana, Cuba.

Lugioyo, G. M. (2003). Distribución, relaciones tróficas y diversidad del bacterioplancton de las aguas oceánicas de Cuba (Tesis de Doctorado). Universidad de la Habana, Cuba.

Lugioyo, G. M., Miravet, M. E., Pérez, R., Álvarez, C., \& Espinosa, G. (2007). Evaluación del estado trófico de las aguas oceánicas adyacentes al sur de Cuba a partir de indicadores microbiológicos y fitoplanctónicos. Revista Investigaciones Marinas, 28, 201-207.

McClanahan, T. R., Carreiro-Silva, M., \& DiLorenzo, M. (2007). Effect of nitrogen, phosphorous, and their interaction on coral reef algal succession in Glover's Reef, Belize. Marine Pollution Bulletin, 54, 1947-1957.
Meesters, H. E., Bos, A., \& Gast, G. J. (1992). Effects of sedimentation and lesion position on coral tissue regeneration. Seventh international coral reef symposium, Guam, 2, 671-678.

Mumby, P. J., \& Steneck, R. S. (2008). Coral reef management and conservation in light of rapidly-evolving ecological paradigms. Trends Ecology Evolution, 23, 555-563.

Orozco-Llerena, M. V. (1997). Microzooplancton en las aguas oceánicas al sur de Cuba (Tesis de Maestría). Universidad de La Habana, Cuba.

Pandolfi, J., \& Jackson, J. B. C. (2001). Community structure of Pleistocene coral reefs of Curaçao, Netherland Antilles. Ecology Monographic, 71, 49-67.

Pandolfi, J. M., Jackson, J. B. C., Baron, N., Bradbury, R. H., Guzman, H. M., Hughes, T. P., ... Sala, E. (2005). Are US coral reefs on the slippery slope to slime? Science, 307, 1725-1726.

Patterson, K. L., Porter, J. W., Ritchie, K. B., Polson, S. W., Mueller, E., Peters, E. S., ... Smith, G. W. (2002). The etiology of white pox, a lethal disease of the Caribbean elkhorn coral, Acropora palmata. Proceedings of the National Academy of Sciences, 99, 8725-8730.

Pavlidis, Y. A., Ionin, A. S., Ignatov, E. I., Luis, M., \& Avelio, O. (1973). Condiciones de la formación de la oolita en las regiones someras de los mares tropicales. Serie Oceanológica, 18, 1-18.

Perera, S., Alcolado, P. M., Caballero, H., Guardia, E., \& Cobián, D. (2013). Condición de los arrecifes coralinos del Parque Nacional Guanahacabibes, Cuba. REVMAR, 5, 41-62.

Pérez, R., Gil, C., \& Loza, S. (1990). Variaciones estacionales de fitoplancton en aguas oceánicas al sur de Cuba (Informe Final). Cuba: Instituto de Oceanología de Cuba.

Precht, W. F., Bruckner, A., Aronson, W. R. B., \& Bruckner, R. J. (2002). Endangered acroporid corals of the Caribbean. Coral Reef, 21, 41-42.

Rogers, C. S. (1990). Responses of coral reefs and reef organisms to sedimentation. Marine Ecology Progress Series, 62, 185-202.

Rogers, C. S., \& Miller, J. (2006). Permanent 'phase shifts' or reversible declines in coral cover? Lack of recovery of two coral reefs in St. John, US Virgin Islands. Marine Ecology Progress Series, 306, 103-114.

Sheppard, C. R. C. (1982). Coral population on reef slopes and their major controls. Marine Ecology Progress Series, 7, 83-115. 
Schuttenberg, H., \& Marshall, P. (2008). Managing for mass coral bleaching: Strategies for supporting socioecological resilience. In C. Wilkinson and D. Souter (Eds.), Status of Caribbean Coral Reefs after Bleaching and Hurricanes in 2005 (pp. 115-127). Townsville, Australia: Global Coral Reef Monitoring Network and Rainforest Research Centre.

StatSoft, Inc. (2002). STATISTICA 6.0 for Windows (Computer Program Manual). Tulsa, Oklahoma, USA: StatSoft.
Torres, J., \& Morelock, J. (2002). Effect of Terrigenous Sediment Influx on Coral Cover and Rates of Three Caribbean Massive Coral Species. Caribbean Journal Science, 1, 222-229.

Wessel, P., \& Smith, W. H. F. (1996). A global, self-consistent, hierarchical, high-resolution shoreline database. Geophysics Journal, 101, 8741-8743.

Wolanski, E., Fabricius, K., Spagnol, S., \& Brinkman, R. (2005). Fine sediment budget on an inner-shelf coral-fringed island, Great Barrier Reef of Australia. Estuarine Coast Shelf Science, 65, 153-158.

\section{APPENDIX I}

Results of the permutational multivariate analysis of variance (PERMANOVA) based on the Bray-Curtis dissimilarity index for coral parameters at crest-reefs sites

\begin{tabular}{|c|c|c|c|c|c|c|c|}
\hline \multirow{2}{*}{ Indicator } & \multicolumn{7}{|c|}{ PERMANOVA table of results } \\
\hline & Source & df & SS & MS & Pseudo-F & $\mathrm{P}($ perm $)$ & perms \\
\hline \multirow[t]{3}{*}{ Coral cover } & Sites & 3 & 11586 & 3862 & 27.438 & 0.001 & 998 \\
\hline & Res & 67 & 9430.6 & 140.76 & & & \\
\hline & Total & 70 & 21017 & & & & \\
\hline \multirow[t]{3}{*}{ Coral density } & $\overline{\text { Sites }}$ & 3 & 857.08 & 285.69 & 2.6455 & 0.047 & 999 \\
\hline & Res & 70 & 7559.3 & 107.99 & & & \\
\hline & Total & 73 & 8416.4 & & & & \\
\hline \multirow[t]{3}{*}{ Maximun diameter } & Sites & 3 & 42962 & 14321 & 56.722 & 0.001 & 998 \\
\hline & Res & 525 & 132550 & 252.47 & & & \\
\hline & Total & 528 & 175510 & & & & \\
\hline \multirow[t]{3}{*}{ Coral relative abundance } & Sites & 3 & 91184 & 30395 & 28.625 & 0.001 & 999 \\
\hline & Res & 70 & 74329 & 1061.8 & & & \\
\hline & Total & 73 & 165510 & & & & \\
\hline
\end{tabular}


APPENDIX II

Relative abundance (\%) of corals by site

\begin{tabular}{|c|c|c|c|c|c|c|c|c|c|c|c|c|c|c|c|c|}
\hline \multirow{2}{*}{$\begin{array}{l}\text { Ecological zone } \\
\text { Depths (m) }\end{array}$} & \multicolumn{4}{|c|}{ Crest } & \multicolumn{12}{|c|}{ Fore-reefs } \\
\hline & 1.5 & 1.5 & 1.5 & 1.5 & 10 & 15 & 20 & 10 & 15 & 20 & 10 & 15 & 20 & 10 & 15 & 20 \\
\hline & \multicolumn{16}{|c|}{ Sites } \\
\hline Species & SW1 & SW2 & $\mathrm{C} 1$ & SE1 & N1 & N2 & N3 & SW3 & SW4 & SW5 & $\mathrm{C} 2$ & $\mathrm{C} 3$ & $\mathrm{C} 4$ & SE2 & SE3 & SE4 \\
\hline Siderastraea siderea & 0.0 & 0.0 & 1.0 & 11.6 & 35.2 & 36.7 & 36.4 & 19.8 & 18.9 & 8.2 & 31.7 & 13.7 & 23.5 & 25.7 & 39.1 & 29.1 \\
\hline Porites astreoides & 13.7 & 27.1 & 3.8 & 36.2 & 8.9 & 6.0 & 1.4 & 9.8 & 16.0 & 5.7 & 19.5 & 20.5 & 3.6 & 14.6 & 5.0 & 5.5 \\
\hline Orbicella faveolata & 0.0 & 0.0 & 1.1 & 0.0 & 14.3 & 20.4 & 20.4 & 6.5 & 9.9 & 17.9 & 7.4 & 14.7 & 29.9 & 13.4 & 12.6 & 15.5 \\
\hline Agaricia agaricites & 0.0 & 0.0 & 0.0 & 0.0 & 5.8 & 4.5 & 7.8 & 24.2 & 17.3 & 28.2 & 4.5 & 6.0 & 12.2 & 12.4 & 9.8 & 14.8 \\
\hline Millepora complanata & 53.0 & 61.5 & 8.1 & 22.0 & 0.0 & 0.0 & 0.0 & 0.0 & 0.0 & 0.0 & 0.0 & 0.0 & 0.0 & 0.0 & 0.0 & 0.0 \\
\hline Acropora palmata & 15.9 & 5.4 & 82.0 & 0.0 & 0.0 & 0.0 & 0.0 & 0.0 & 0.0 & 0.0 & 0.0 & 0.0 & 0.0 & 0.0 & 0.0 & 0.0 \\
\hline Stephanocoenia intercepta & 0.0 & 0.0 & 0.0 & 0.0 & 9.9 & 11.2 & 6.5 & 3.7 & 2.8 & 10.2 & 1.4 & 6.5 & 1.1 & 7.6 & 13.2 & 18.2 \\
\hline Orbicella annularis & 2.5 & 0.0 & 0.7 & 6.0 & 4.6 & 4.3 & 1.8 & 13.5 & 14.1 & 5.6 & 5.8 & 7.0 & 4.7 & 3.8 & 1.0 & 0.0 \\
\hline Porites furcata & 12.0 & 6.1 & 0.6 & 2.5 & 3.2 & 0.0 & 0.0 & 0.9 & 2.3 & 1.0 & 7.4 & 7.8 & 0.0 & 5.1 & 1.1 & 0.0 \\
\hline Porites porites & 0.0 & 0.0 & 0.0 & 11.9 & 6.0 & 3.1 & 0.8 & 3.0 & 6.4 & 1.7 & 4.5 & 5.5 & 1.1 & 1.0 & 2.0 & 0.0 \\
\hline Agaricia lamarcki & 0.0 & 0.0 & 0.0 & 0.0 & 0.0 & 0.4 & 8.4 & 1.3 & 1.8 & 8.6 & 0.0 & 0.0 & 11.3 & 0.8 & 3.9 & 5.4 \\
\hline Montastraea cavernosa & 0.0 & 0.0 & 0.0 & 0.0 & 5.1 & 3.7 & 1.9 & 4.2 & 3.2 & 3.1 & 7.9 & 1.2 & 0.0 & 3.6 & 1.1 & 0.9 \\
\hline No. of transects & 18 & 17 & 22 & 18 & 15 & 15 & 16 & 15 & 14 & 16 & 15 & 16 & 15 & 15 & 15 & 15 \\
\hline
\end{tabular}

Only $95 \%$ of species counted at crest and fore-reefs sites is represented. See codes of sites in Table 1.

\section{APPENDIX III}

Results of the permutational multivariate analysis of variance (PERMANOVA) based on the Bray-Curtis dissimilarity index for biological trait data of fore-reefs sites

\begin{tabular}{|c|c|c|c|c|c|c|c|}
\hline \multirow{2}{*}{ Indicator } & \multicolumn{7}{|c|}{ PERMANOVA table of results } \\
\hline & Source & df & SS & MS & Pseudo-F & $\mathrm{P}($ perm $)$ & perms \\
\hline \multirow[t]{5}{*}{ Coral cover } & Location & 3 & 588.62 & 196.21 & 3.8105 & 0.010 & 999 \\
\hline & Depth & 2 & 304.64 & 152.32 & 2.9582 & 0.046 & 997 \\
\hline & Location $\mathrm{x}$ depth & 6 & 197.87 & 32.978 & 0.6405 & 0.715 & 999 \\
\hline & Res & 165 & 8496 & 51.491 & & & \\
\hline & Total & 176 & 9575.9 & & & & \\
\hline \multirow[t]{5}{*}{ Coral density } & Location & 3 & 949.81 & 316.6 & 8.9117 & 0.001 & 999 \\
\hline & Depth & 2 & 62.058 & 31.029 & 0.8734 & 0.409 & 999 \\
\hline & Location $\mathrm{x}$ depth & 6 & 288.37 & 48.062 & 1.3528 & 0.232 & 999 \\
\hline & Res & 170 & 6039.6 & 35.527 & & & \\
\hline & Total & 181 & 7337.9 & & & & \\
\hline \multirow[t]{5}{*}{ Maximun diameter } & Location & 3 & 53858 & 17953 & 26.785 & 0.001 & 998 \\
\hline & Depth & 2 & 11902 & 5951.2 & 8.8793 & 0.001 & 999 \\
\hline & Location $\mathrm{x}$ depth & 6 & 5357.1 & 892.86 & 1.3322 & 0.200 & 999 \\
\hline & Res & 2149 & 1440300 & 670.24 & & & \\
\hline & Total & 2160 & 1513600 & & & & \\
\hline \multirow[t]{5}{*}{ Coral relative abundance } & Location & 3 & 35941 & 11980 & 11.258 & 0.001 & 999 \\
\hline & Depth & 2 & 26738 & 13369 & 12.562 & 0.001 & 998 \\
\hline & Location $\mathrm{x}$ depth & 6 & 17496 & 2916.1 & 2.7401 & 0.001 & 998 \\
\hline & Res & 171 & 181980 & 1064.2 & & & \\
\hline & Total & 182 & 262000 & & & & \\
\hline
\end{tabular}


APPENDIX IV

Results of Pair-Wise Tests (PERMANOVA) of coral parameters at crest-reefs sites

\begin{tabular}{|c|c|c|c|c|}
\hline Indicator & Groups & $\mathrm{t}$ & $\mathrm{P}($ perm $)$ & perms \\
\hline \multirow[t]{6}{*}{ Coral cover } & SW1. SW2 & 0.220 & 0.888 & 998 \\
\hline & SW1. C1 & 5.985 & 0.001 & 997 \\
\hline & SW1. SE1 & 3.455 & 0.001 & 998 \\
\hline & SW2. C1 & 6.888 & 0.001 & 998 \\
\hline & SW2. SE1 & 3.627 & 0.001 & 998 \\
\hline & C1. SE1 & 7.625 & 0.001 & 999 \\
\hline \multirow[t]{6}{*}{ Coral density } & SW1. SW2 & 0.975 & 0.339 & 693 \\
\hline & SW1. C1 & 0.550 & 0.600 & 897 \\
\hline & SW1. SE1 & 0.409 & 0.722 & 828 \\
\hline & SW2. C1 & 1.407 & 0.160 & 943 \\
\hline & SW2. SE1 & 0.486 & 0.672 & 896 \\
\hline & C1. SE1 & 0.758 & 0.435 & 985 \\
\hline \multirow[t]{6}{*}{ Maximun diameter } & SW1. SW2 & 1.630 & 0.084 & 997 \\
\hline & SW1. C1 & 5.767 & 0.001 & 998 \\
\hline & SW1. SE1 & 2.047 & 0.030 & 998 \\
\hline & SW2. C1 & 6.802 & 0.001 & 999 \\
\hline & SW2. SE1 & 2.086 & 0.032 & 998 \\
\hline & C1. SE1 & 4.333 & 0.001 & 999 \\
\hline \multirow[t]{6}{*}{ Coral relative abundance } & SW1. SW2 & 1.1714 & 0.278 & 998 \\
\hline & SW1. C1 & 7.1125 & 0.001 & 999 \\
\hline & SW1. SE1 & 3.2597 & 0.001 & 997 \\
\hline & SW2. C1 & 10.732 & 0.001 & 998 \\
\hline & SW2. SE1 & 3.0614 & 0.001 & 999 \\
\hline & C1. SE1 & 6.4779 & 0.001 & 999 \\
\hline
\end{tabular}

See codes of sites in Table 1 . 
APPENDIX V

Results of Pair-Wise Tests (PERMANOVA) of coral parameters at fore-reefs sites

\begin{tabular}{|c|c|c|c|c|c|c|c|c|c|c|}
\hline \multirow{2}{*}{ Indicator } & \multirow{2}{*}{$\begin{array}{l}\text { Depth } \\
\text { Groups }\end{array}$} & \multicolumn{3}{|c|}{$10 \mathrm{~m}$} & \multicolumn{3}{|c|}{$15 \mathrm{~m}$} & \multicolumn{3}{|c|}{$20 \mathrm{~m}$} \\
\hline & & $\mathrm{t}$ & $\mathrm{P}($ perm $)$ & perms & $\mathrm{t}$ & $\mathrm{P}($ perm $)$ & perms & $\mathrm{t}$ & $\mathrm{P}($ perm $)$ & perms \\
\hline \multirow[t]{6}{*}{ Coral cover } & N. C & 1.529 & 0.149 & 997 & 0.746 & 0.463 & 997 & 0.260 & 0.857 & 998 \\
\hline & N. SW & 0.840 & 0.436 & 999 & 0.886 & 0.393 & 998 & 0.468 & 0.718 & 997 \\
\hline & N. SE & 2.014 & 0.058 & 998 & 1.063 & 0.280 & 997 & 1.056 & 0.323 & 999 \\
\hline & C. SW & 0.599 & 0.597 & 999 & 0.549 & 0.596 & 997 & 0.260 & 0.849 & 999 \\
\hline & C. SE & 2.995 & 0.004 & 998 & 0.674 & 0.522 & 999 & 1.397 & 0.179 & 999 \\
\hline & W. SE & 2.087 & 0.038 & 998 & 1.269 & 0.191 & 997 & 1.572 & 0.115 & 991 \\
\hline \multirow[t]{6}{*}{ Coral density } & N.C & 2.065 & 0.040 & 904 & 1.294 & 0.207 & 910 & 0.663 & 0.594 & 948 \\
\hline & N. SW & 1.087 & 0.305 & 837 & 1.153 & 0.251 & 896 & 3.270 & 0.003 & 979 \\
\hline & N. SE & 0.760 & 0.446 & 950 & 1.437 & 0.154 & 934 & 0.285 & 0.850 & 979 \\
\hline & C. SW & 2.545 & 0.017 & 917 & 2.831 & 0.010 & 809 & 3.522 & 0.001 & 861 \\
\hline & C. SE & 1.983 & 0.056 & 936 & 0.232 & 0.861 & 832 & 0.769 & 0.502 & 903 \\
\hline & W. SE & 0.365 & 0.739 & 903 & 2.891 & 0.007 & 786 & 2.572 & 0.019 & 958 \\
\hline \multirow[t]{6}{*}{ Maximun diameter } & N.C & 1.230 & 0.230 & 999 & 0.330 & 0.889 & 998 & 2.640 & 0.004 & 999 \\
\hline & N. SW & 2.528 & 0.005 & 998 & 2.783 & 0.002 & 997 & 1.336 & 0.171 & 999 \\
\hline & N. SE & 4.186 & 0.001 & 997 & 2.845 & 0.004 & 999 & 3.934 & 0.001 & 998 \\
\hline & C. SW & 3.638 & 0.001 & 998 & 2.538 & 0.003 & 999 & 3.956 & 0.001 & 998 \\
\hline & C. SE & 5.302 & 0.001 & 998 & 2.622 & 0.008 & 999 & 6.524 & 0.001 & 998 \\
\hline & W. SE & 1.564 & 0.104 & 998 & 0.766 & 0.486 & 997 & 2.668 & 0.005 & 999 \\
\hline \multirow[t]{6}{*}{ Coral relative abundance } & N. C & 1.628 & 0.017 & 999 & 2.346 & 0.001 & 999 & 1.727 & 0.016 & 998 \\
\hline & N. SW & 2.464 & 0.001 & 999 & 2.360 & 0.001 & 998 & 2.092 & 0.001 & 999 \\
\hline & N. SE & 1.612 & 0.011 & 999 & 0.821 & 0.671 & 998 & 1.212 & 0.189 & 999 \\
\hline & C. SW & 2.061 & 0.001 & 999 & 1.837 & 0.002 & 999 & 1.878 & 0.001 & 998 \\
\hline & C. SE & 1.622 & 0.018 & 998 & 2.490 & 0.001 & 999 & 2.170 & 0.001 & 998 \\
\hline & W. SE & 1.770 & 0.001 & 999 & 2.472 & 0.001 & 999 & 1.768 & 0.002 & 998 \\
\hline
\end{tabular}

See codes of location in Table 1. 
